\title{
DETECTION OF SALMONELLAE IN SOME MEAT PRODUCTS
}

Nader Y. Moustafa ; Ibrahim I. Al-Hawary and Reda M. Ibrahim Food control dep. Fac. of Vet. Med., Kafrelsheikh univ., Egypt.

\section{ABSTRACT}

A total of 150 samples of meat products (34 sausage, 35 beef burger, 39 minced meat and 42 luncheon samples) were collected randomly from different markets at Kafr-El-sheikh and El-Gharbiah governorates on Egypt the samples were examined for isolation and identification of Salmonella Spp.. The PCR results showed that salmonella Spp were detected in 4 (11.8\%), 1(2.9\%), 2 (5.1\%) samples of examined sausage, beef burger and minced meat samples, respectively and not detected in luncheon samples. The isolated salmonellae were S. kentucky, S.saintpaul and S.tounouma in sausage samples, S.liverpool in beef burger samples and S. muenster and S. hadar in minced meat samples. These results showed that sausage, beef burger and minced meat might represent a source for salmonella as a food borne disease for human being.

\section{INTRODUCTION}

Meat and meat products are high in moisture, nitrogenous compounds, minerals, growth factors, fermentable carbohydrates (glycogen) and of favorable $\mathrm{pH}$, that provides a suitable environment for proliferation of meat spoilage microorganisms and common food-borne pathogens (Aymerich et al., 2008). Processed meats are the result of the need to preserve meat in ancient times. The knowledge to preserve meat by making fermented sausages was already known in ancient times (Pederson, 1980). 
Food borne disease and microbial spoilage of food result from the failure or inability to control microorganisms at one or more stages of the food chain from raw material production to consumption of the final product (Afshin et al., 2011).

Food borne infections and illnesses is a major international health problem with consequent economic reduction. It is a major cause of illness and death worldwide (Adak et al., 2005).

Salmonellosis is one of the major food borne diseases. Due to its endemic nature, high morbidity and association with a wide range of foods, this zoonotic disease is of high public health concern (Kottwitz et al., 2008).There are several transmission routes for salmonellosis, but the major route of human infections is the consumption of contaminated foods especially those of animal origin (Hernandez et al., 2005).The public health hazard of salmonella food poisoning in causing selflimiting gastroenteritis characterized by diarrhoea, abdominal cramps and sometimes vomiting and fever and also Typhoid and paratyphoid fevers (Rhoades et al., 2009).

Therefore the aim of the present study was to throw the light on the incidence, isolation and identification of Salmonellae from some meat products.

\section{MATERIAL AND METHODS}

\section{1- Collection of samples}

A total of 150 random samples of meat products (34 sausage, 35 beef burger, 39 minced meat and 42 luncheon samples) were collected randomly from different markets at Kafr-El-sheikh and El-Gharbiah 
governorates. The collected samples were transferred directly to the laboratory in their packages. The samples were immediately examined bacteriologically for the isolation and identification of salmonellae.

\section{2- Isolation and identification of salmonella:}

2.1. Isolation of salmonellae according to (ISO, 2002).

\subsection{Identification of salmonella:}

\subsubsection{Biochemical identification:}

The suspected colonies were purified and identified biochemically according to (Cruickshank et al., 1975) and (FDA, 1998).

2.2.2 PCR confirmation: (according to Ahmed et al., 2007)

\subsubsection{Bacterial DNA preparation}

\subsubsection{PCR amplification:}

Amplification condition step was performed using a pair of primers specific for the species gene fragment of Salmonella for amplification of the extracted DNA. Primers specific for the species gene fragment of Salmonella:

Salmonella forward primer: 5'- ATCGCTGACTTATGCAATCG $3^{\prime}$ and Salmonella reverse primer: 5'- CGGGTTGCGTTATAGGTCTG $3^{\prime}$.

PCR amplification was carried out using $0.5 \mathrm{ml}$ PCR tube, in which $25 \mu 1$ of PCR mixture were added for each sample (5 $\mu 1$ Taq Master Mix $5 \mathrm{X}, 1.25 \mu \mathrm{l}$ from working solution of each primers, $5 \mu \mathrm{l}$ of extracted DNA and $12.50 \mu$ l distilled water).

The amplification was performed in a DNA thermal cycler (Peltier thermal cycler, USA). 
Table (1): The PCR amplification cycles condition

\begin{tabular}{|c|c|c|c|c|}
\hline Steps & Cycles & Objective & Temperature & Time \\
\hline First step:(1) & 1 & Preheating & $95^{\circ} \mathrm{C}$ & 2 minutes \\
\hline \multirow[t]{3}{*}{ Second step: (3) } & \multirow{3}{*}{30} & Denaturation & $95^{\circ} \mathrm{C}$ & 1 minute \\
\hline & & Annealing & $57^{\circ} \mathrm{C}$ & 1 minute \\
\hline & & Extension & $72{ }^{\circ} \mathrm{C}$ & 2 minute \\
\hline Third step: (1) & 1 & Final extension & $72^{\circ} \mathrm{C}$ & 5 minutes \\
\hline Fourth step: (1) & 1 & Holding & $4^{\circ} \mathrm{C}$ & 99.99 minutes \\
\hline
\end{tabular}

The amplicons of $204 \mathrm{bp}$ of Salmonella species-specific fragments were visualized by running in $1 \%$ agarose gel by using horizontal gel electrophoresis

\subsubsection{Serological identification}

The confirmed salmonellae were serologically examined in Clinical Microbiology unit of central health laboratory, Ministry of Health, cairo, Egypt.

\section{RESULTS}

Table (2): Incidence of salmonellae in the examined meat products samples

\begin{tabular}{|c|c|c|c|}
\hline \multirow{2}{*}{ Type of examined samples } & \multirow{2}{*}{ No. of examined samples } & \multicolumn{2}{|c|}{ Positive samples } \\
\hline & & No. & $\%$ \\
\hline Sausage & 34 & 4 & 11.8 \\
\hline Beef burger & 35 & 1 & 2.9 \\
\hline Minced meat & 39 & 2 & 5.1 \\
\hline Luncheon & 42 & 0 & 0 \\
\hline
\end{tabular}

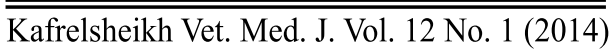




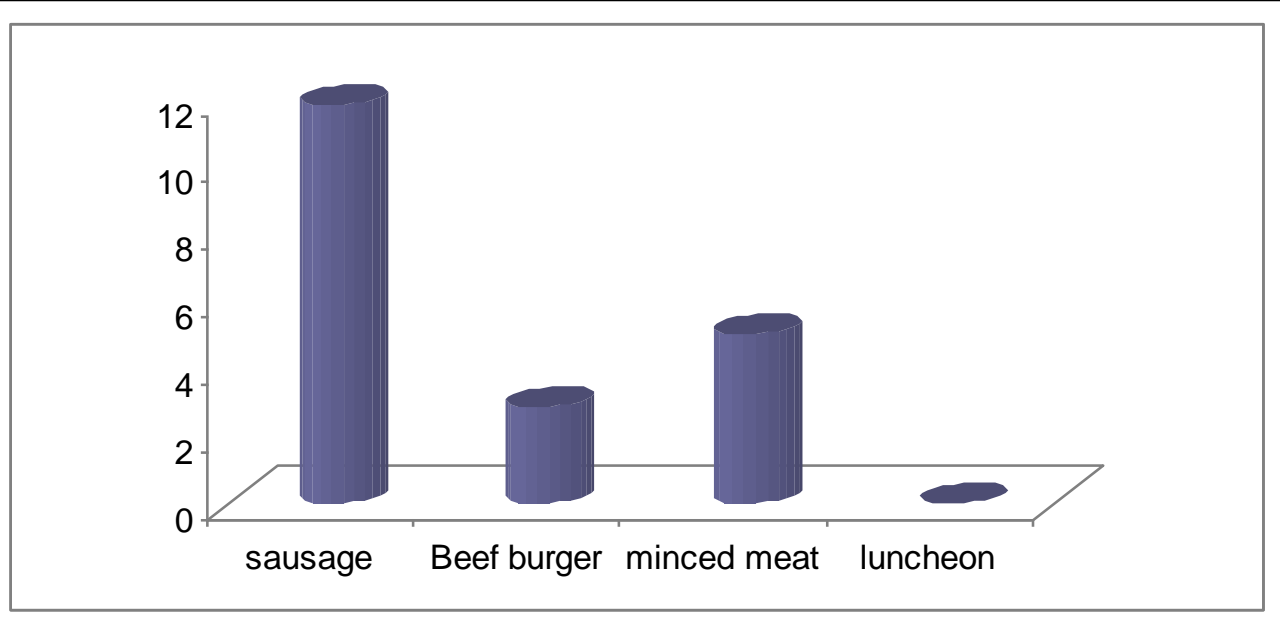

Fig. (1): Incidence of salmonella in the examined meat products samples.

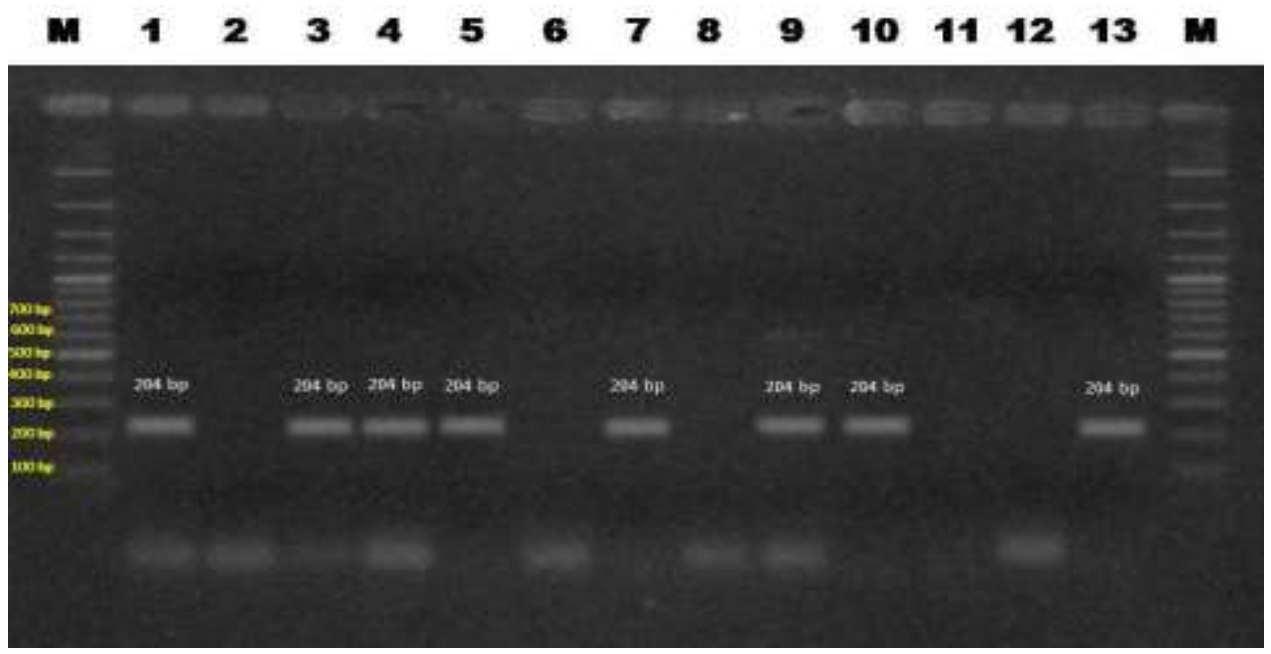

Fig. (2): Agarose gel Electrophoresis of PCR shows that ( $M=$ ladder $100 \mathrm{bp}$, lane 1 control positive, lane 2 control negative, lane 3,4,5,7 the isolated Salmonella spp from sausage samples, lane 6 negative sausage sample, lane 8 negative minced meat sample, lane 9, 10 the isolated Salmonella spp from minced meat samples, lane 11 negative luncheon sample, lane 12 negative beef burger sample, lane 13 the isolated Salmonella spp from beef burger sample. 
Table (3): Serotyping of salmonella isolated from the examined meat products samples.

\begin{tabular}{||c||c||c||}
\hline $\begin{array}{c}\text { Types of examined } \\
\text { samples }\end{array}$ & $\begin{array}{c}\text { No. of Positive } \\
\text { samples }\end{array}$ & +Serovars \\
\hline \hline Sausage & 4 & S. Kentucky(2 samples), S. saintpaul andS.tounouma \\
\hline Beef burger & 1 & S.liverpool \\
\hline Minced meat & 2 & \\
\hline Luncheon & 0 & \\
\hline
\end{tabular}

\section{DISCUSSION}

The meat industry is the main reservoir of Salmonella as food borne pathogen which arise from dirt from the hide, as well as dirt of process equipment contaminate carcasses during slaughter and packing house operations (Braden, 2006). Consumption of raw or under cooked meat products might cause several food poisoning diseases such as salmonellosis.

It's evident from the results recorded in table (2) and figure 1 and 2 that sausage samples had the higher incidence of Salmonella contamination followed by minced meat then beef burger samples with percentage of $11.8 \%, 2.9 \%, 5.1 \%$, respectively. While Salmonellae could not be detected in the examined luncheon samples.

Nearly similar results were obtained by Eleiwa, (2003), Fath ElBab-Gehad et al., (2006) and Essam, (2010), Lower results were obtained by CORTEZ et al., (2008), Tassew et al., (2010) and Sezer et al., (2013). Higher results were obtained by Ejeta et al., (2004), Mrema et al., (2006) and Hassanein et al., (2011) and salmonella could not detected in any samples (Reham, 2004, Malicki and Bruzewicz, 2005 and Nagwa, 2009). 
The high incidence of Salmonella in sausage may be attributed to the fact that this product is made from raw meat in addition to natural casing is often used in the manufacture which may be important source of Salmonella specially in absence of proper hygiene (Field et al., 1977). While in minced meat may be due to cutting and contamination of meat besides the increase in its water and oxygen contents as well as contamination from grinders, air, packaging materials and hands of the workers. Temperature rise $\left(2-4^{\circ} \mathrm{C}\right)$ during grinding could also increase the incidence of Salmonella organisms (Gobran, 1985).

The presence of even small numbers of M.Os in carcass meat and edible offals may also lead to heavy contamination of minced meat and sausage when meat cutted into pieces, more microorganisms are added to the surfaces of exposed tissue (Darwish et al., 1986).

The absence of Salmonellae in luncheon meat may be due to the addition of food additives such as spices and preservatives, which have an antimicrobial activity and inhibit survival and multiplication of microorganisms (Moffatt et al., 2006). This also may be due the exposure to high temperature during processing and cooking procedures.

From the result recorded in table (2), it's clear that Salmonella serovars identified from fresh sausage samples were 2 strains as $S$. Kentucky, one strain as S.saintpaul and one strain as S.tounouma and in the examined beef burger samples one Salmonella serovar was isolated and identified as S.liverpool. While in the examined minced meat samples the Salmonella serovars were identified as one strain of $S$. muenster and one strain of $S$. hadar. 
From the results of the present study, it could be concluded that Salmonella contaminated sausage, beef burger and minced meat samples obtained from retail supermarkets in Kafr-El-Sheikh and El- Gharbia, Egypt. They could be a potential vehicle for food-borne infections and implementation of preventive measures and consumer food safety education efforts are needed. Proper cooking of meat products before consumption and improving personal hygiene in the line of meat products production from farm to processing plant to ensure the safety of meat products for human consumption.

\section{REFERENCES}

- Adak, G. K., Meakins, S. M., Yip, H., Lopman, B. A. and O'Brien, S. J. (2005). Disease risks from foods, England and Wales, 1996-2000. Emerging infectious diseases 11, 365.

- Afshin, J., Reza, Z. and Saeid, S. (2011). Microbiological Study of Cocktail Sausage During Shelf Life. Middle-East Journal of Scientific Research 7, 1056-1056.

- Ahmed, A. M., Motoi, Y., Sato, M., Maruyama, A., Watanabe, H., Fukumoto, Y. and Shimamoto, T. (2007). Zoo animals as reservoirs of gram-negative bacteria harboring integrons and antimicrobial resistance genes. Applied and Environmental Microbiology 73, 6686-6690.

- Aymerich, T., Picouet, P. and Monfort, J. (2008). Decontamination technologies for meat products. Meat Science 78, 114-129.

- Braden, C. R. (2006). Salmonella enterica serotype Enteritidis and eggs: a national epidemic in the United States. Clin Infect Dis $43,512-7$. 
- CORTEZ, A. L. L., CARVALHO, A., AMARAL, L., SALOTTI, B. and VIDAL-MARTINS, A. (2008). Fecal coliform, coagulase positive Staphylococci(CPS), Salmonella spp. and Campylobacter spp. in fresh sausage. Alimentos e Nutrição Araraquara 15, 215-220.

- Cruickshank, R., Duguid, J. P., Marmion, B. P. and Swain, R. H. A. (1975). Medical microbiology. Churchilli Livingstone, Edinburgh 2, 119 .

- Darwish, A., Hamdy, M. and Nouman, T. (1986). Quality evaluation of market meat pastes. Vet. Med. J 34, 37-48.

- Ejeta, G., Molla, B., Alemayehu, D. and Muckle, A. (2004). Salmonella serotypes isolated from minced meat beef, mutton and pork in Addis Ababa, Ethiopia. Revue de médecine vétérinaire 155, 547-551.

- Eleiwa, N. Z. H. (2003). Effect of chemical preservatives on food poisoning bacteria in some locally manfactured meat products. Ph.D.Thesis, Meat Hygiene. Fac. Vet. Med., Zagazig University.

- Essam, I. M. E.-T. (2010). plasmid profile analysis of salmonellae isolated from some meat products. Phd.Sc. (Meat hygiene), Fac. Veteterinary. Medicine. Banha university.

- Esteves, A., Saraiva, C., Fontes, M. and Martins, C. (2006). Hygienic quality and safety of traditional meat products from particular producers of Trás-os-Montes. Revista Portuguesa de Ciências Veterinárias 557, 109.

- Fath El-Bab-Gehad, Sayed, E. and Ismail, T. (2006). Bacteriological and chemical studies of frozen sausage in Giza province. Zag. Vet. J. 34, 156-163.

- Food and Drug Agency (FDA) (1998). Bacteriological analytical manual 8th Edition. AOAC international, Gaithersburg, USA. 
- Field, R. A., Smith, F. C., Deane, D. D., Thomas, G. M. and Kotula, A. W. (1977). Sources of variation at the retail level in bacteriological condition of ground beef. Journal of Food Protection 40, 385-388.

- Gobran, R. A. (1985). Enterobacteriaceae in meat products in Upper Egypt. M.V.Sc., Fac. Vet. Med. Assuit Univ.

- Hassanein, R., Ali, S. F. H., El-Malek, A. M. A., Moemen, A. M. and Elsayh, K. I. (2011). Detection and identification of Salmonella species in minced beef and chicken meats by using Multiplex PCR in Assiut city. Veterinary World 4, 5-11.

- Hernandez, T., Sierra, A., Rodriguez-Alvarez, C., Torres, A., Arevalo, M. P., Calvo, M. and Arias, A. (2005). Salmonella enterica serotypes isolated from imported frozen chicken meat in the Canary islands. J Food Prot 68, 2702-6.

- International Organization for Standardization (ISO) (2002). Microbiology of food and animal feeding stuffs - Horizontal method for detection of Salmonella spp. 6579 .

- Kottwitz, L. B. M., Back, A., Leão, J. A., Alcocer, I., Karan, M. and Oliveira, T. C. R. M. (2008). Contaminação por Salmonella spp. em uma cadeia de produção de ovos de uma integração de postura comercial. Arquivo Brasileiro de Medicina Veterinária e Zootecnia 60, 496-498.

- Malicki, A. and Bruzewicz, S. (2005). Microbiological status of minced meat directly post production is influenced by its internal temperature and $\mathrm{pH}$ value. Electronic Journal of Polish Agricultural Universities. Series Veterinary Medicine 8.

- Moffatt, C. R., Combs, B. G., Mwanri, L., Holland, R., Delroy, B., Cameron, S. and Givney, R. C. (2006). An outbreak of Salmonella Typhimurium phage type 64 gastroenteritis linked to catered luncheons in Adelaide, South Australia, June 2005. Communicable Diseases Intelligence 30, 443. 
- Mrema, N., Mpuchane, S. and Gashe, B. A. (2006). Prevalence of Salmonella in raw minced meat, raw fresh sausages and raw burger patties from retail outlets in Gaborone, Botswana. Food Control 17, 207-212.

- Nagwa, T. W. A. E.-H. A. (2009). Bacteriological and histological evaluation of some meat products. M. V. Sc. (Meat hygiene), Fac. Vet. Med. Karelsheikh university.

- Pederson, C. S. (1980). Microbiology of Food Fermentations (Mikrobiologie von Lebensmittel-Fermentation). Second Edition, The AVI Publishing Company, Inc., Westport/Connecticut (USA) 1979.

- Reham, A., A. (2004). Microbial evaluation of some meat products. M. V. Sc. (Meat hygiene), Fac. Vet. Med. Zagazig Univeristy, (Benha Branch).

- Rhoades, J. R., Duffy, G. and Koutsoumanis, K. (2009). Prevalence and concentration of verocytotoxigenic Escherichia coli, Salmonella enterica and Listeria monocytogenes in the beef production chain: a review. Food Microbiol 26, 357-76.

- Sezer, Ç., Aksoy, A., Çelebi, Ö., Deprem, T., Öğ̈̈̈n, M., Oral, N. B., Vatansever, L. and Güven, A. (2013). Evaluation of the quality characteristics of fermented sausages and sausage-like products sold in Kars. Eurasian Journal of Veterinary Sciences 29, 143-149.

- Tassew, H., Abdissa, A., Beyene, G. and Gebre-Selassie, S. (2010). Microbial flora and food borne pathogens on minced meat and their susceptibility to antimicrobial agents. Ethiopian journal of health sciences 20. 
الكثف عن السالمونيلا في بعض منتجات اللحوم

نظرا لأهميه منتجات اللحوم كمصدر غذائي هام فقد اجريت هذه الدراسه علي بعض منتجات

اللحوم في محافظتي كفرالثيخ والغربية وذللك للتعرف علي مدي ثلوثها ميكروب السالمونيلا المسبب لبعض الامراض الهامه للانسان مثل حمي التنفويد والنزلات المعويه. لذا فقد نم تجميع عدد 150 عينه ومن منتجات اللحوم 34 عينه سجق، 35 عينه بيف برجر، 39 عينه لحم مفروم و 42 عينه لانشون. وقد أسفرت النتائج عن نواجد السالمونيلا هي 11.8\%، 2.9\%، 5.1\% و 0 \% في السجق، البيف برجر، اللحم المفروم واللانشون علي التوالي. وكانت العترات المعزوله هي S. Kentucky، S.tounouma S.saintpaul

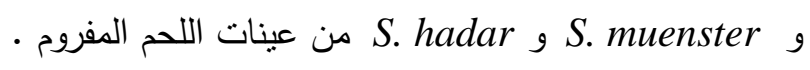

ووقد نوقتت هذه النتائج لمعرفه الاسباب المختلفه لتواجد السالمونيلا بهذه المنتجات والتي أكدت

عدم اتباع الاساليب الصحيه السليمه لتصنيع هذه المنتجات وذللك للوصول في النهايه لمنتج صحي امن لضمان سلامه المستهلك. 